\title{
Survey on Existing Status of the Animals in Rangpur Zoo of Bangladesh
}

\author{
M Ashraful Kabir* \\ Department of Biology, Nilphamari, Bangladesh
}

*Corresponding author: M Ashraful Kabir, Department of Biology, Nilphamari, Bangladesh.

Received Date: Janury 19, 2019

Published Date: January 30, 2019

\begin{abstract}
Rangpur Zoo of Bangladesh is the second government zoo after Dhaka Mirpur Zoo (National Zoo of Bangladesh). Its area is 20.75 acre which was established in the year 1989. This zoo was opened for the people at 14 September 1991. Due to the exhibition of various animals and for increasing animal research, this Zoo and Recreational Park has been established. Here, total animals were 184 including reptiles, aves, and mammals. According to the results of this study, proper manpower and shortages of medical facilities in this zoo is hampered. Animals are suffered by indigestion, catch cold and tuberculosis. Immediately need to provide animals' hospital, isolation room, and veterinary surgeon in this zoo. Out of 30 animals the reptilian were 3(10\%), aves 17(56.67\%), and mammals $10(33.33 \%)$ respectively. A great problem is continuing here that in case of Lion, Hyena, Hippopotamus, Cassowary, and Ass all were male and Tiger and Bear were female. Same sex fighting and in Monkey, they were suffering sexual problems. Need to maintain male female ratio of Deer 1:6. One Indian Peafowl is male, and another is albino male. Already an application was submitted to the concern authority to collect those animals for their paring. If some rare animals like Zebra, Giraffe, Elephant, Leopard, Ostrich, Chimpanzee, and Gibbon being introduced it would be an excellent zoo of the country. Vitamin deficiency is common in zoo animals especially in Tiger and Lion.
\end{abstract}

Keywords: Animal; Existing status; Rangpur zoo

\section{Introduction}

Zoos are primarily such facilities where animals are confined within enclosures, and in which they may also be bred. Such facilities include safari park, aviaries, butterfly park, and reptile center as well as wildlife sanctuaries and nature reserves. In Bangladesh zoos are- Chittagong Zoo, Comilla Zoo, Dhaka Zoo, Dulahazra Safari Park, Bhawal National Park, Bangabandhu Sheikh Mujib Safari Park, Nijhum Dip Park, Rajshahi Zoo, and Rangpur Zoo. Within these only Dhaka and Rangpur is the government zoo and others are private. Safari parks are good for observing the animals with biodiversity in a natural state where animals live freely and can perform natural breeding. Many of today's zoos hope to stop or slow the decline of many endangered species. Many zoos see their primary purpose as breeding endangered species in captivity and reintroducing them into the wild. However, zoo advocates argue that their efforts make a difference in wildlife conservation and education [1]. Bangladesh zoos are associated to donate or exchange of the animals with Saudi Arabia, Iraq, Kuwait, and Bahrain. In any zoos need an animal museum, vet hospital, investigation and research section [2]. Shortages of manpower, supply of feed, care, enclosure maintenance, various establishments, protection, conservation, guidelines for common visitors, and administration all are not positive in this zoo. There is no vet hospital, isolation room, and vet surgeon so it is being burden to detect the diseases of zoo animals. Immediately need to establish new buildings. Present administrative office of the zoo is under the place of horticulture. There is no vehicle of this zoo. This zoo earns a lot of revenue from various sources- pond lease, canteen, children park, parking, and garden. Sex identification of some animals and exchange male or female is urgent in this zoo. The objective of this study is to solve above adverse situations.

\section{Materials and Methods}

Observed animals: In Rangpur Zoo there were total 30 animals. In reptilian group animals are- Rock Python (Python molurus), Gavial (Gavialis gangeticus), Saltwater Crocodile (Crocodylus porosus), in birds- Greater and Lesser Adjutant (Leptoptilos dubius and L. javanicus), Night Heron (Nycticorax nycticorax), Indian Pond 
Heron (Ardeola grayii), Intermediate Egret (Mesophoyx intermedia), Purple Moorhen (Porphyrio porphyrio), Black Kite (Milvus migrans), Brahminy Kite (Haliaster indus), Long-billed Vulture (Gyps indica), Rose-ringed Parakeet (Psittacula krameri), Alexandrine Parakeet (Psittacula eupatria), Common Peafowl (Pavo cristatus), Demoiselle Crane (Grus virgo), Grey-headed Fish Eagle (Ichthyophaga ichthyaetus), Lesser Spotted Eagle (Aquila pomarina), Barn Owl

Table 1: Present organogram.

Manpower

\begin{tabular}{|c|c|c|c|c|c|}
\hline Sl. No & Name of Post & Authorized Post & In Service & Empty Post & Comments \\
\hline 1 & Deputy Curator & 1 & 1 & None & - \\
\hline 2 & Zoo Officer & 1 & 1 & None & - \\
\hline 3 & $\begin{array}{c}\text { Higher Assistant Cum } \\
\text { Accountant }\end{array}$ & 1 & - & 1 & - \\
\hline 4 & Office Assistant & 1 & 1 & None & - \\
\hline 5 & Carpenter & 1 & 2 & None & - \\
\hline 6 & Gardener & 2 & 5 & None & Transferred \\
\hline 7 & Guard & 6 & 2 & None & From Dhaka Zoo \\
\hline 8 & MLSS & 2 & 2 & None & - \\
\hline 9 & Mnimal Caretaker & 1 & 5 & & - \\
\hline 10 & Master roll worker & 5 & & & - \\
\hline
\end{tabular}

*updated 19 March 2014 by Deputy Curator of Rangpur Zoo.

\section{Interview, Questionnaire and Survey}

Huge visitors' come in zoo with their family. It has a great value to collect information from them about animals. Its safety measure for the public and cleanliness of the cages all are very important mammals are-African Lion (Panthera leo), Indian Tiger (Panthera $t$. tigris), Asian Black Bear (Ursus thibetanus), Striped Hyena (Hyaena striata), Rhesus Monkey (Macaca mulatta), Olive Baboon (Papio anubis), Hippopotamus (Hippopotamus amphibious), Spotted Deer (Axis axis), and Indian Crested Porcupine (Hystrix indica) (Table 1).
(Tyto alba), Southern Cassowary (Casuarius casuarius), and

Table 2: Comments sheet of the visitors.

\begin{tabular}{|c|c|c|}
\hline Questions & \multicolumn{2}{|c|}{ Comments (put $\sqrt{\text { mark) }}$} \\
\hline Main entrance & Satisfactory & Not satisfactory \\
\hline Ticket price & Satisfactory & Not satisfactory \\
\hline Environment of zoo & Satisfactory & Not satisfactory \\
\hline Animals are getting enough space and privacy & Satisfactory & Not satisfactory \\
\hline Condition of animals & Satisfactory & Not satisfactory \\
\hline Health of animals & Satisfactory & Not satisfactory \\
\hline Cleanliness within the zoo & Satisfactory & Not satisfactory \\
\hline Information sign about animals & Satisfactory & Not satisfactory \\
\hline Condition of plants in zoo & Satisfactory & Not satisfactory \\
\hline Cafeteria inside the zoo is okay? & Satisfactory & Not satisfactory \\
\hline Food quality of cafeteria in the zoo & Satisfactory & Not satisfactory \\
\hline Photographic places & Satisfactory & Not satisfactory \\
\hline Condition of washroom & Satisfactory & Not satisfactory \\
\hline With family, it is & Satisfactory & Not satisfactory \\
\hline How children felt? & Satisfactory & Not satisfactory \\
\hline Road/Passage within this zoo & Satisfactory & Not satisfactory \\
\hline Any bad incident has happened? & Yes & No \\
\hline \multicolumn{3}{|l|}{ Your profession/occupation } \\
\hline \multicolumn{3}{|l|}{ Which cage is beautiful? } \\
\hline \multicolumn{3}{|l|}{ Any suggestions for the improvement of this zoo? } \\
\hline Compare this zoo with another zoos home and abroad. & & \\
\hline Where from you knew about this zoo? & & \\
\hline
\end{tabular}

NB Please fill-up this form and put in the comment box when you will leave this zoo. 


\section{Result}

In this zoo, for the heavy weight of python snake its egg cannot hatch. For avoiding this incident need to buy an incubator machine

Table 3: Present status of the animal in Rangpur Zoo. immediately. All Gharials are female here; need to exchange these reptiles with other zoos. Greater Adjutant, Purple Moorhen, Parakeet, Demoiselle Crane, Cassowary, Lion, Hyaena, Baboon, Hippopotamus, Porcupine, and Donkey needs female (Table 3).

\begin{tabular}{|c|c|c|c|c|}
\hline English Name & Scientific Name & Distribution & Global Status & Comments \\
\hline Rock Python & Python molurus (Linnaeus 1758) & MEF, S & LR & problem for hatching \\
\hline Gavial & Gavialis gangeticus (Gmelin, 1789) & Padma River & CR & not seen mating \\
\hline Saltwater Crocodile & Crocodylus porosus, Schneider 1801 & S & LC & need to sex identify \\
\hline Greater Adjutant-stork & Leptoptilos dubius, Gmelin 1789 & IS & EN & need female \\
\hline Lesser Adjutant-stork & L. javanicus, Horsfield 1821 & $\mathrm{~W}$ & $\mathrm{VU}$ & okay \\
\hline Black-crowned Night Heron & Nycticorax nycticorax (Linnaeus 1758) & IS & LC & okay \\
\hline Purple Moorhen & Porphyrio porphyrio (Linnaeus 1758) & IS & LC & need female \\
\hline Black Kite & Milvus migrans, Boddaert 1783 & IS & LC & need more \\
\hline Brahminy Kite & Haliaster indus, Boddaert 1783 & IS & LC & need more \\
\hline Long-billed Vulture & Gyps indica (Scopoli 1786) & IS & CR & okay \\
\hline Rose-ringed Parakeet & Psittacula krameri (Scopoli 1769) & IS & LC & need female \\
\hline Alexandrine Parakeet & Psittacula eupatria (Linnaeus 1766) & IS & NT & need female \\
\hline $\begin{array}{l}\text { Indian Peafowl (one is } \\
\text { albino) }\end{array}$ & Pavo cristatus, Linnaeus 1758 & IS & LC & need female \\
\hline Demoiselle Crane & Grus virgo (Linnaeus 1758) & IS & LC & need female \\
\hline Grey-headed Fish Eagle & $\begin{array}{l}\text { Ichthyophaga ichthyaetus (Horsfield } \\
1824 \text { ) }\end{array}$ & IS & NT & okay \\
\hline Lesser Spotted Eagle & Aquila pomarina (Brehm 1831) & AEA & LC & need sex identify \\
\hline Barn Owl & Tyto alba (Scopoli 1769) & $\mathrm{W}$ & LC & okay \\
\hline Southern Cassowary & Casuarius casuarius (Linnaeus 1758) & Papua New Guinea (Australia) & $\mathrm{VU}$ & need female \\
\hline African Lion & Panthera leo (Linnaeus 1758) & Africa & $\mathrm{VU}$ & need female \\
\hline Indian Tiger & Panthera t. tigris (Linnaeus, 1758) & S & EN & need male \\
\hline Asian Black Bear & Ursus thibetanus, G. Cuvier 1823 & MEF & VU & need male \\
\hline Striped Hyena & Hyaena striata (Linnaeus 1758) & Africa, Asia & NT & need female \\
\hline Rhesus Monkey & Macaca mulatta (Zimmermann, 1780) & $\mathrm{W}$ & LC & okay \\
\hline Olive Baboon & Papio anubis (Lesson 1827) & Africa & LC & need female \\
\hline Hippopotamus & $\begin{array}{l}\text { Hippopotamus amphibius, Linnaeus } \\
1758\end{array}$ & Africa & VU & need female \\
\hline Spotted Deer/Chital & Axis axis (Erxleben, 1777) & S & LC & okay \\
\hline Indian Crested Porcupine & Hystrix indica, Kerr 1792 & $\mathrm{~W}$ & LC & need female \\
\hline $\begin{array}{c}\text { Domesticated European } \\
\text { Rabbit }\end{array}$ & Oryctolagus cuniculus (Linnaeus 1758) & Europe, Africa & $\mathrm{D} / \mathrm{P}$ & okay \\
\hline Donkey & Equus africanus asinus, Linnaeus 1758 & $\mathrm{AC}$ & $\mathrm{D}$ & need female \\
\hline Indian Pond Heron & Ardeola grayii (Sykes 1832) & IS & LC & need more \\
\hline Intermediate Egret & Mesophoyx intermedia (Wagler 1827) & IS & LC & need more \\
\hline
\end{tabular}

*LR=Least Risk; LC=Least Critical; EN=Endangered; NT=Near Threatened; VU=Vulnerable; D/P=Domestic/Pet; MEF=Mixed Evergreen Forest; $W=$ Widely distributed; $S=$ Sundarbans; $A C=$ Asian Countries; IS=Indian Subcontinent; $A E A=A$ sia Europe Africa.

\section{Discussion}

In safari park riding on animals especially horse and elephant are sometimes another major causes for attack. Need to handle in circus animals while it is performing [3]. Zoo also remains opens to the visitors during government holidays [2]. Wildlife tourism [4-7] and ecotourism [8] have been published which were the best guide to the beginners. Finucane and Dowling [3] made a study on perception of ecotourism operations in Western Australia. Distribution of ecotourism services of Bangladesh and its potentials with development were described by $[9,10]$. Anorexia and vitamin deficiency are very common to the zoo animals. Elephants usually travel around 30 miles each day and sometimes perform headbobbing, bears sometimes pace the surrounds of their enclosure, wild cats sometimes groom themselves obsessively, and parrots have been known to pluck themselves. Elephants have been recorded displaying stereotypical HYPERLINK

"http://en.wikipedia.org/wiki/Stereotypy_\%28nonhuman\%29"behaviours in the form of swaying back and forth, 
trunk swaying or route tracing. This has been observed in 54\% of individuals in UK zoos [11]. Elephants in European zoos have shorter lifespan than their wild counterparts at only 17 years, although other studies suggest that zoo elephants live as long those in the wild [12]. There are animals that are injured in wild but live healthy and happy life in zoo.

\section{Conclusion}

During feeding the zoo animals and poor enclosure can be dangerous for visitors in zoo. If zoos are concerned with recreation park causes problem of zoo animals. In some mini zoos, some authority's free adjutant-stork and emu but it can be fatal to people. Safari park can be a good way for conservation of animals. Research is must for the welfare zoo animals but need to maintain huge scientific precautions. In breeding season, most zoo animals always show anger. For avoiding such conflicts with the human or among them, we should know their exact breeding season. For the purpose of treatment of the zoo animals especially carnivorous animals their careful handling is very important. Experienced animal trainer should appoint in zoos. Newly introduced animals in zoos are suffered some common illness with anxiety and depression. Visitors should apply their sympathy to all animals. Serve the leaflets to visitors before entering in zoos. Ensure a job for a Zoology student/Wildlife Researcher in any zoos. Maintain a register and comment box for the future prospects of the zoo. Weekly seminar is important for sharing the current status of all animals and establishments. Make a special list of carnivorous or man-eating animals. Zoo can be a key point to the practitioners and academics for research $[13,14]$.

\section{Acknowledgement}

Author is giving special thanks to the Deputy Curator A. S. M. Nasir Uddin Khan of Rangpur Zoo, Bangladesh for delivering complete present status of his zoo. He mentioned animal status, their feed, disease and treatment. In addition, he mentioned his foreign life when he took part in Denmark for the degree of PGT.
Veterinary Surgeon Mr. Nasir was very cordial officer who allowed me in his zoo and delivered all information during walking within the zoo. He permitted me to write this article and was a proofreader of this manuscript.

\section{Conflicts of Interest}

No conflicts of interest.

\section{References}

1. Masci D (2000) Zoos in the $21^{\text {st }}$ Century. CQ Researcher 353-76.

2. ZOOS' PRINT (2006) 1(12), December 2006 (RNI 8:3).

3. Kabir MA (2013) Circus tradition of Bangladesh and fate in its animals. South Pacific Journal of Pharma and Bio Science (1): 51-57.

4. Orams MB (1996) A conceptual model of tourist-wildlife interaction: the case for education as a management strategy. Australian Geographer 21(1): 39-51.

5. Ryan C, Huyton J (2000) Who is interested in aboriginal tourism in the northern territory, Australia? A cluster analysis. Journal of Sustainable Tourism 8(1): 53-88.

6. Shackley M (1996) Wildlife tourism. Routledge, London.

7. Shackley M (2001) Flagship species: case studies in wildlife tourism management. Burlington, VT. International Eco-tourism Society.

8. Weaver D (2001) Ecotourism, Milton, John Wiley and Sons, Australia.

9. Afjal HM, Uddin, Kamal, Sheel, Kumar S (2005) Potentials of tourism development in Bangladesh: an empirical study. Dhaka University Journal of Business Studies 26(1).

10. Afjal HM, Uddin, Kamal, Sheel, Kumar S (2003) Distribution of tourism services in Bangladesh: an evaluation of the role of different tourism firms, DU Journal of Marketing 6.

11. Harris, M, Sherwin C, Harris S (2011) Defra Final Report on Elephant Welfare. University of Bristol.

12. Mott M (2008) Wild elephants live longer than their zoo counterparts. National Geographic News.

13. Malakar B, Khan MMH, Chakraborty L (2007) The zoo as ecotourism attraction- visitor reactions and perceptions: the case of Dhaka Zoo, Bangladesh.

14. Finucane, Sonia J, Ross DK (1995) The perceptions of ecotourism operators in Western Australia. Tourism Recreation Research 20(1). 